\title{
HIV and Hepatitis Infections in Children Resident in Orphanage Homes Located In Anambra State, Nigeria
}

\author{
Oluboyo, B.O ${ }^{1}$., Enweani, I.B ${ }^{2}$., Ekejindu, I.M²., Oluboyo, A.O ${ }^{2}$ \\ ${ }^{1}$ Molecular Diagnostic Laboratory, Nnamdi Azikiwe University Teaching Hospital, Nnewi, Anambra State, \\ Nigeria. \\ ${ }^{2}$ Department of Medical Laboratory Science, Faculty of Health Sciences and Technology, College of Health \\ Sciences, Nnamdi Azikiwe, University, Nnewi Campus, Anambra State, Nigeria.
}

\begin{abstract}
Human immunodeficiency virus (HIV) and hepatitis infections are among viral infections transmissible among inmates of orphanage and motherless babies' homes. Records are scanty on the prevalence of HIV and hepatitis infections in children resident in orphanage homes in Anambra State, Nigeria. This study investigated the prevalence of HIV and Hepatitis infections in children resident in eight orphanages in Anambra State. A total of 300 subjects consisting of 172 orphans, 100 children from community setting serving as controls, 14 female consented care givers in the orphanages and 14 females in community setting served as controls. All the subjects and control groups were investigated for HIV using rapid test and molecular technique. ELISA assay and liver enzyme estimation were used for Hepatitis investigation. The prevalence of $0.6 \%, 0.0 \%, 0.6 \%$, and $9.9 \%$ were observed in HIV, hepatitis $A, B$ and $C$ respectively. Liver enzymes (serum alanine and aspartate amino transferases) did not show significant increase. The viral load and CD4+ count of the HIV positive child were 373 copies $/ \mathrm{ml}$ and $28 \%$ respectively. Three $(21.4 \%)$ of the care givers in the orphanages tested positive to HCV infection while none of the females in the community tested positive to the virus. HCV infections were most common in ages 0-5 years. The infection may be at dormant phase in the homes. Thus, continuous monitoring for progression into active hepatitis $C$ infection is necessary for disease management in the orphanage homes.
\end{abstract}

Keywords: Prevalence, HIV, Hepatitis, infections, Orphanages.

\section{Introduction}

HIV and natural disasters are responsible for the large and increasing number of orphans ${ }^{1}$ (WHO, 2007). Worldwide, it is estimated that more than 15 million children under 18 have been orphaned as a result of AIDS. Around 11.6 million of these children live in sub-Saharan Africa ${ }^{2}$ (UNAIDS, 2008). Even with the expansion of antiretroviral treatment access, it is estimated that by 2015, the number of orphaned children will still be overwhelmingly high (UNAIDS, 2008). Most of the available data are concerned with the number of children orphaned by HIV/AIDS, TB, and other diseases and mishaps ${ }^{3}$ (UNICEF, 2013). Records are scanty on the prevalence of HIV and hepatitis in the orphanages in Nigeria. The after effects of HIV/AIDS, hepatitis deaths and deaths due to other preventable diseases are the increase in the number of orphans and there may be possibility of spread of infections in orphanages as they may not be regularly visited for the purpose of public health concerns. HIV and HCV may spread among children in orphanages due to vertical transmission and sexual abuse. Early detection of these viruses in children is of immense value in disease management.

The study therefore aimed at investigating the prevalence of HIV and Hepatitis infections in children resident in eight orphanages in Anambra State.

\section{Materials and methods}

Three hundred (300) children consisting of 172 children ( 79 males and 93 females) and 100 children (50 males and 50 females) in the community setting serving as control groups, 14 female consented care givers in the orphanages and 14 females care givers in community setting serving as controls, were investigated for HIV using HIV rapid testing serial algorism and HIV-1 DNA PCR (for children between 6 weeks and 18 months old). Viral Load and CD4+ count of HIV positive children were determined using HIV-1 RNA monitor test and The New model cycle counter 2 (Partec, Germany) respectively. Hepatitis B surface antigen (HBsAg) and Hepatitis $\mathrm{C}$ virus (HCV) infections were determined using Enzyme linked immunosorbent assay (ELISA) technique. Liver enzymes (Alanine aminotransferase and aspartate aminotranseferase) estimation was further carried out on the hepatitis positive subjects and some hepatitis negative subjects to serve as controls using the method of Reitman and Frankel ${ }^{4}$. The research subjects were grouped into four age ranges of 5-year intervals for the purpose of identifying age range most infested. 


\section{Results}

The overall prevalence recorded was $10.1 \%$ with $\mathrm{HCV}$ having the highest prevalence of $9.9 \%$ and Hepatitis A virus (HAV) having the least prevalence of $0.0 \%$ (Table 1.0 ). A prevalence of $0.6 \%, 0.0 \%, 0.6 \%$ and $9.9 \%$ were recorded for HIV, HAV, HBV and HCV respectively in the 8 orphanage homes (Table 1.0). In control subjects, the prevalence was $0.0 \%, 0.0 \%, 0.0 \%, 3.0 \%$ respectively. Five of the children tested positive with HIV rapid test. One (1) out of the 5 children was confirmed HIV-1 DNA positive resulting to a prevalence of $0.6 \%$. The viral load and CD4+ count of the HIV infected child was 372,528 copies/ml and $23.18 \%$ respectively.

Seventeen $(9.9 \%)$ children out of 172 in the orphanage homes tested positive for HCV which comprised 11(6.4\%) female and $6(3.5 \%)$ males (Table 1.0). The prevalence of HCV infection was found to be significant $(\mathrm{p}<0.05)$ when children resident in the orphanages $(9.9 \%)$ were compared with children in the community setting $(3.0 \%)$ (Table 2.0$)$

The prevalence of Hepatitis $\mathrm{C}$ virus infection in children resident in orphanage homes was not significant with respect to ages $(\mathrm{p}>0.05)$. The age group of $0-5$ year recorded the highest frequency $(14$ out of 17 positive cases. i.e. $82.4 \%$ ) of HCV positivity (Table 3.0). HCV was not significantly associated with gender $(\mathrm{p}>0.05)$.

The alanine aminotransferase (ALT) and aspartate aminotranseferase (AST) levels of hepatitis B positive and Hepatitis $\mathrm{C}$ positive children were not elevated in relation to the results from children free of hepatitis infection $(\mathrm{p}>0.05)$ (Table 4.0).

\section{Discussion}

The children who tested positive to serological HIV assay may have acquired only the antibody to HIV and not the virus from their mother. The only child that was confirmed to be HIV positive may have become infected with HIV through vertical transmission from mother to child. The viral load of the HIV positive child was high and the CD4\% was low enough (Viral load and CD4+ count was 372,528 copies/ml and 23.18\% respectively) to warrant antiretroviral drugs. Infants and children having CD4+ count lower than $25 \%$ are recommended for anti-retroviral treatment ${ }^{5,6}$ This child was registered in HIV Clinic for further management. The observed HIV prevalence in this study was contrary to the work ${ }^{7}$ that reported a prevalence of $1.05 \%$ in seven orphanage homes in the South Western Nigeria. A higher prevalence of $7.2 \%$ was reported for HIV infection among pregnant antenatal women in Benin City ${ }^{8}$ although it was in a different population. There is paucity of information on the prevalence of HAV in children in Nigeria. World Health Organization (WHO) reported that HAV infection in children under 6 years of age do not usually experience noticeable symptoms and only $10 \%$ of such children develop jaundice ${ }^{9}$. There is a sporadic occurrence of the virus and in epidemics throughout the world with a tendency for cyclic recurrences.

HBsAg prevalence of $0.6 \%$ reported in this study was lower than $7.8 \%$ in HIV infected children in Markudi, Nigeria within the same age range of children in this study ${ }^{10}$. HIV may have weakened the immune system of the children and make them more vulnerable to other infections. This may explain the high prevalence of HBsAg in HIV infected children. Furthermore, a prevalence of 2.2\% for HBV was reported among pregnant women $^{8}$. The 15 year old female child who was HBV positive in this study may have acquired the virus through vertical transmission as she is the only one in the orphanage home who tested positive to the virus. Although she is apparently healthy with normal ALT level, she could be in immune tolerant phase of HBV infection. It is estimated that $90 \%$ of children infected with HBV virus, and $25-50 \%$ of children who became infected after early infancy but before 5 years of age, will develop chronic infection ${ }^{11}$. Only $5-10 \%$ of teenagers or young adults who become infected with the virus progress to chronic infection. Although they may be asymptomatic and severe liver disease during childhood is rare, they are at risk of developing serious complications such as liver cirrhosis and hepatocellular carcinoma (HCC) later in life. Routine lifelong monitoring was recommended for progression of disease and potential opportunities for treatment as cardinal step to their management.

The findings of this research (HCV prevalence of $9.9 \%$ in 8 orphanages) supports the report that Nigeria is classified as highly endemic for viral hepatitis with a prevalence of $2.7-13.3 \%$ in normal population ${ }^{12}$, 13, 14 . The reason for higher prevalence in this study might be due to cross infection in the orphanages through sexual abuse or vertical transmission to the children from their sexually active teenage mothers. HCV prevalence of $3.0 \%$ in children in the community setting in this study was higher than $0.9 \%$ recorded in children in same setting (community) in Ibadan, Nigeria ${ }^{15}$. It is estimated that the prevalence of $\mathrm{HCV}$ is $0.2 \%$ in children younger than 12 years of age and $0.4 \%$ in those between $12-19$ years of age ${ }^{16}$. This is lower than the prevalence recorded in this study against children in the orphanage homes in Anambra State. It has been reported that the rate of transmission among HCV infected mothers who also had HIV is $25.0 \%$ compared to $3.8 \%$ in mothers who did not have HIV ${ }^{17}, 18$. The five infants who tested positive to HIV antibodies in this study is an indication of the HIV status of their mother. The high HCV infection reported in this study (ages of 0 and 5 years.) may have been transmitted through Mother-to-Child Transmission. Horizontal transmission may also 
account for a little fraction of the prevalence. The occurrence of the virus is not significant across the age grades as older children tested negative to the virus in the various orphanage homes. However, their serum transferases were normal. This supports the report that in chronic cases of HCV infection, the serum transferases levels were said to be normal or mildly abnorma ${ }^{16}$.

\section{Conclusion}

Lifelong monitoring for disease progression is of immense value in the management of chronic hepatitis infection. Periodic assessment of ALT levels of the hepatitis positive children is needed for early diagnosis of active infection and subsequent medication.

\section{References}

[1]. World Health Organization (2007). The World Health Report 2007 - A safer future: global public health security in the 21st century. Geneva: World Health Organization.

[2]. UNAIDS (2008): Report on global AIDS epidemics. http://www.avert.org/africa-hiv-aids-statistics.htm

[3]. UNICEF (2013). Towards an AIDS-Free Generation - Children and AIDS: Sixth Stocktaking Report, 2013. http://www.unifef.org/publications/index_70986. (Assessed May 2nd 2014).

[4]. Reitman and Frankel (1957). American Journal of Clinical Pathology. 28: 56

[5]. Paediatric European Network for Treatment of AIDS. PENTA 2009 guidelines for the use of antiretroviral therapy in paediatric HIV-1 infection. 2009, http://www.pentatrials.org (Assessed (12 $2^{\text {th }}$ May, 2012).

[6]. World Health Organization. Antiretroviral therapy for HIV infection in infants and children: Towards universal access. 2010.http://www.int/hiv/pub/paediatric/infants2010/en/index.html (Assessed 12th January, 2012)

[7]. Oladokun, R. E., Brown, B. J., Jacob, N. and Osinusi, E. K. HIV infection in orphanages in South Western. Nigeria. Nigerian Journal of Paediatrics, 2011, 38 (1): Abstract.

[8]. Oladeinde, B. H., Omoregie, R. and Oladeinde, O. B. Prevalence of HIV, HBV, and HCV infections among pregnant women receiving antenatal care in a traditional birth home in Benin City, Nigeria. Saudi Journal of Health Sciences, 2013, 2:113-117.

[9]. World Health Organization. Hepatitis A. Fact Sheet No. 328. 2013. who.int/mediacentre/factsheets/fs328/en/ (Assessed May 22, 2014).

[10]. Anigilaje, E. A. and Olutola, A. Human immunodeficiency virus and hepatitis C virus co-infection among children in an antiretroviral therapy programme in Benue. The Internet Journal of Infectious Diseases, 2013, 12 (1). http://ispub.com/IJID/12/1/1420.

[11]. McMahon B. J, Alward W. L, Hall D. B, Heyward W. L, Bender T. R, Francis D. P and Maynard J. E. Acute hepatitis B virus infection: relation of age to the clinical expression of disease and subsequent development of the carrier state. Journal of Infectious Diseases, 1985, 151: $599-603$.

[12]. Heber, B. A., Block, J. M., Jonas, M. M., Karpen, S. J., London, W. T., McMahon, B. J., Murray, K. F., Narkeicz, M. R., Rosenthal, P, and Schwarz, K. B. Recommendation for screening, monitoring, and referral of pediatric chronic hepatitis B. Pediatrics, 2009, 124: $1007-1013$.

[13]. Ejiofor, O.S., Ibe, B.C., Emodi, I. J., Ikefuna, A. N., Ilechukwu, G. C., Emechebe, G. and Ilechukwu, C. (2009). The role of blood transfusion on the prevalence of hepatitis $\mathrm{C}$ virus antibodies in children with sickle cell anaemia in Enugu, South East Nigeria, 2009, 12 (4):355-358.

[14]. Onuchukwu, C., Ojuawo, A. and Ernest, S. Hepatitis C virus antibodies among transfused children with sickle cell anaemia at University of Ilorin Teaching Hospital. Open Journal of Pediatrics, 2013, 3, 195-200. doi: 10.4236/ojped.2013.33034

[15]. Okonkwo, I., Adepoju, A., Okerentungba, P., Nwanze, J. and Onoh C. Detection of Hepatitis C Virus (Hcv) Antibody among Children in Ibadan, Southwestern Nigeria. The Internet Journal of Gastroenterology, 2012, 11 (1).

[16]. Rosenthal, P. Hepatitis C in children. A publication of the hepatitis C support project. Medical writers' circle. The HCV Advocate, 2009, pp 1-2.

[17]. Mast, E. E., Hwang, L. Y., Seto, D. S Y., Nolte, F. S., Nainan, O. V., Wurtzel, H. and Alter, M. J. Risk factors for perinatal transmission of hepatitis $\mathrm{C}(\mathrm{HCV})$ and the natural history of $\mathrm{HCV}$ infection acquired in infancy. Journal of Infectious Diseases, 2005, 192 (11): 1880 - 1889.

[18]. Muula, A. S. Tackling HIV/AIDS in Africa-another Perspective. African Health, 2000, 23 (1): 5-6.

\begin{tabular}{lllll}
\hline \multicolumn{4}{c}{ Table 1.0: Prevalence of various infections in children resident in orphanage homes in relation to gender } \\
\hline \multicolumn{5}{c}{ Gender } \\
Parameters & No. Positive & Male: $\mathbf{7 9}(\mathbf{4 6 \% )}$ & Female: $\mathbf{9 3}(\mathbf{5 4 \% )})$ & Positive (\%) \\
HIV Test & 1 & $1(1.3)$ & $0(0.0)$ & 0.6 \\
Hepatitis A & 0 & $0(0.0)$ & $0(0.0)$ & 0.0 \\
Hepatitis B & 1 & $0(0.0)$ & $1(1.1)$ & 0.6 \\
Hepatitis C & 17 & $6(7.6)$ & $11(11.8)$ & 9.9 \\
Total & $\mathbf{1 9}$ & $\mathbf{7 ( 8 . 9 )}$ & $\mathbf{1 2}(\mathbf{1 2 . 9})$ & $\mathbf{1 0 . 1}$ \\
\hline
\end{tabular}

$\mathbf{N}=\mathbf{1 7 2}$

\begin{tabular}{lllll}
\hline \multicolumn{5}{r}{ Table 2.0: Prevalence of various infections in children resident in orphanage homes in Anambra State in relation to } \\
the results from children cared for in community setting.
\end{tabular}


$* *-\chi^{2}$ not computed because the parameters were negative

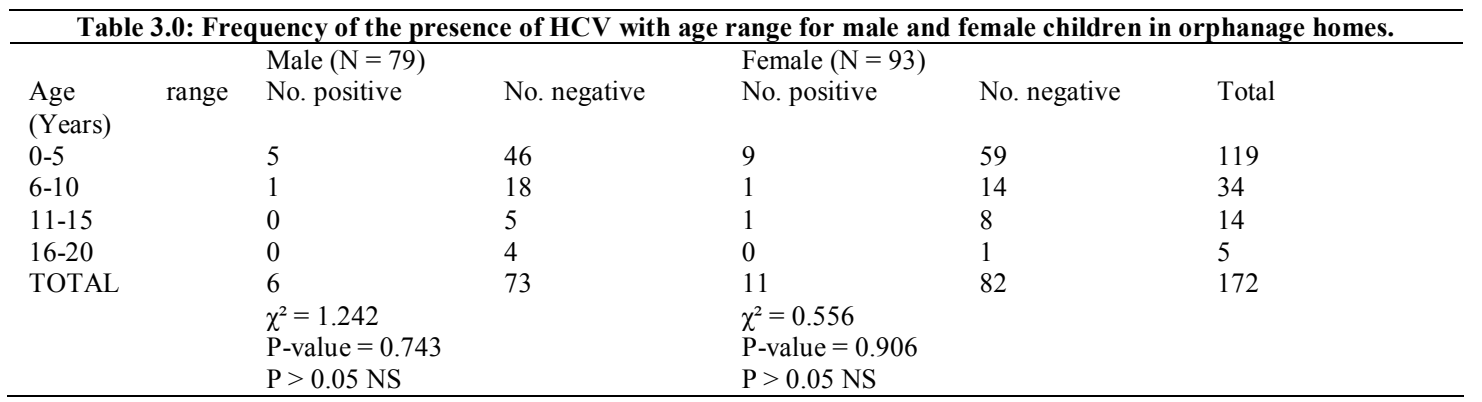

NB: Children whose ages were between 0 and 5 years recorded 14 positive HCV cases out of the total 17 cases in the orphanages giving a prevalence of $82.4 \%$.

\begin{tabular}{llcc}
\hline \multicolumn{4}{c}{$\begin{array}{c}\text { Table 4.0: Mean values of alanine aminotransferase (ALT) and aspartate aminotranseferase (AST) in } \\
\text { hepatitis positive children in relation to children who tested negative to hepatitis test }\end{array}$} \\
\cline { 2 - 4 } & $\begin{array}{l}\text { Mean } \\
\text { Parameter (IU/L) }\end{array}$ & T-value & p-value \\
ALT & $11.39 \pm 3.07$ & & \\
Control & $10.39 \pm 1.50$ & 1.241 & 0.226 \\
AST & $13.61 \pm 2.73$ & & \\
Control & $13.17 \pm 1.69$ & 0.588 & 0.561 \\
\cline { 2 - 4 } & & &
\end{tabular}

$\mathrm{N}=18$ 